\title{
The exchange of curriculum information in Australian education: A review of purposes, practices, and problems
}

\author{
Michael G. Watt
}

\begin{abstract}
This article investigates the patterns and sequences of change in the design of the national system for exchanging information on curriculum-related products within the Australian educational community. The development of the information system is analysed as a function of the missions of the Curriculum Development Centre (CDC) between 1973 and 1989, the Australian Schools Catalogue Information Service (ASCIS) between 1984 and 1989, and the Curriculum Corporation since 1990.
\end{abstract}

The provision of a national information service for teachers on curriculum related products has presented an intractable problem for curriculum planners in the Australian educational setting. Previous research reported by the author identified that the existing program for exchanging information on educational resources within the Australian educational system has failed to satisfy several standards (Watt, 1989). First, the provision of information services has been conducted almost entirely by state departments of education in an uncoordinated way. Second, there is no documented evidence that the activities of this work have been trialed in the field or have been assimilated successfully within the programs of national or state education agencies. Third, research and development activities in the area have been funded inadequately, and appear to have contributed little to the improvement of practice. Fourth, the practices, methods and techniques used to analyse curriculum materials do not provide information that relates to the principles of curriculum design. Fifth, there is no evidence that analysts of curriculum materials have been trained in the skills of instructional design analysis. From further investigation, the author has identified that research into the use of 
curriculum materials in Australian education has not provided useful information on their curriculum role, nor promoted sound decisionmaking in the selection and implementation of instructional materials (Watt, 1991). Furthermore, Broadbent (1983) identified that practices, methods and techniques used to provide school library services and curriculum information services have been inadequately integrated within the Australian educational context. The purpose of this article is to investigate the tenability of these hypotheses through historical and developmental research into the intentions and practices of curriculum planners, and the problems they have encountered in recent efforts to provide curriculum information for Australian teachers.

Soon after the foundation of the Curriculum Corporation in 1990, it became apparent to curriculum planners that the information content of the database inherited by the Curriculum Corporation from the Australian Schools Catalogue Information Service (ASCIS) failed to meet the needs of the Curriculum Corporation in its work relating to the development of a common curriculum framework. This led the Curriculum Corporation to initiate the redesign of the information content of the database and the trialing of new information services during 1991-92. The rationale for this study, part of a larger research project concerned with the investigation of the processes involved in a variety of information services in education, arose from communications during 1991 between the author and the Curriculum and Information Manager of the Curriculum Corporation.

\section{The context of national curriculum collaboration}

Initiatives for curriculum reform in Australian education during the 1960s were stimulated by influences from the curriculum reform movement in the United States and the United Kingdom. State education departments, professional associations and other educational organisations established projects for curriculum reform which led the Commonwealth government to fund the Australian Science Education Project (ASEP) in 1968. For the first time, the ASEP initiated national cooperation between various educational authorities in Australia for the purpose of curriculum development. Moran (1980) reported that such cooperation led educational authorities to lobby the Commonwealth government to establish a national agency for curriculum development, so that these reforms could be extended throughout the country. Founded in June 1973, the Curriculum Development Centre (CDC) was allocated the functions of developing and disseminating school curricula and related curriculum materials. The greater part of the work of the CDC was involved in coordinating projects such as the Social Education Materials Project 
(SEMP), and the Language Development Project (LDP) during the period between 1973 and 1981. The success of this initial period was checked during the 1980s by political constraints and funding restrictions which forced the CDC to close between 1981 and 1984. Hughes and Kennedy (1987) reported that the CDC, when reactivated as one of four divisions of the Commonwealth Schools Commission, was required to collaborate more extensively with state education departments and other educational organisations on projects of curriculum development.

\section{The exchange of cataloguing information}

A similar development towards national collaboration in the cataloguing of educational resources held in school libraries has been reported widely in studies documenting the formation of the ASCIS (Dwyer, 1978; Goodman, 1980; Bahnisch, 1983; Lane and Chisholm, 1984; and Dwyer, 1988). Cooperation between state departments of education for this purpose during the 1970s initiated a series of pilot studies. In 1973, the National Library of Australia trialed the extension of a catalogue card service to schools. A proposal to establish a national cataloguing agency for school libraries was first initiated at a conference of state representatives held in June 1974. As a result, the Commonwealth Schools Commission commissioned two studies, one in 1974 which recommended the establishment of a national agency to provide catalogue cards for schools, and the other in 1977 which specified the requirements for an information system including input from state systems and output provisions in magnetic tape, microfiche and catalogue cards.

The introduction in 1977 by the South Australia Department of Education of the South Australian Education Resources Information System (SAERTS), which provided a database producing output in microfiche and catalogue cards, formed the basis for a two-year pilot study at the national level by the Commonwealth Schools Commission, commencing in April 1978. Intended to provide a bibliographic database of information on instructional materials with output services in catalogue cards and microfiche, the ASCIS Pilot Project used the SAERTS database to form the prospective ASCIS database. Concurrently, three methods were trialed for prospective implementation as a national information service to schools. In the first, cataloguing information was exchanged between the SAERTS and state education authorities. In the second, 166 South Australian schools received copies of the database in the form of microfiche. In the third, 200 Tasmanian schools received the database from a magnetic tape through TASNET, an interactive online system established by the Tasmania Department of Education in 1970. Following the completion of 
the pilot project in July 1980, the Australian Schools Catalogue Information Service Steering Committee (1980) reported five main outcomes: a database of 100,000 records had been developed; software to access the database had been developed; microfiche and catalogue card services had been established; an online cataloguing service had been established in Tasmania; and online access to the database was available through a host service, the Australian Online Information Network (AUSINET).

The success of the trial project led to the formation of a planning group in December 1981 to direct the formative development of the ASCIS. Late in 1983, staff were appointed to form the ASCIS secretariat. Early in 1984, the ASCIS contracted ACI Computer Services to develop a database based upon the Dortmund Bibliographic Information System and the Leuven Integrated Bibliographic System. Following a consultant's report, AUSMARC III was selected as the recognised standard upon which instructional materials held in school libraries should be indexed, with the records providing additional scope for an abstract. Cataloguing agencies were established in the Western Australia Department of Education and the Australian Capital Territory Schools Authority as well as the South Australia Department of Education. These agencies solicited materials from school libraries, publishers, booksellers and government agencies. The 150,000 indexed records, contributed by these three cataloguing agencies, formed the basis for the Schools Catalogue Information Service (SCIS) file on the database, when the national service was initiated in August 1984. At that time, the service provided annually cumulated computer output microfiche supplemented by monthly updates of newly indexed records, catalogue card sets, and magnetic tapes. In 1986, online access was provided to the SCIS file, and the service also incorporated the dissemination of the database on microcomputer diskettes. Eventually, the SCIS file grew to contain 400,000 records, and the ASCIS provided services to 4,000 Australian schools.

As the outcome of an initiative by the Western Australia Department of Education in 1980, the Commonwealth Schools Commission established a one-year project in March 1982 to create a subject headings list to provide a controlled vocabulary for teacher-librarians to index and retrieve information on instructional materials from the ASCIS database. Compiled by two project officers from various lists of subject headings used for library cataloguing, the subject headings list was field-tested and revised on the basis of trialing at a sample of schools and state cataloguing agencies during 1983. The subject headings list, which uses Australian English terms, is designed so that it can be used by school students. The Australian Schools Catalogue Information Service (1985) followed the first edition with a second, published in 1989, which incorporated 700 additions and changes. 


\section{The exchange of curriculum information}

Broadbent and Kemp (1983) have reviewed activities during the 1970s to provide information on curriculum products to Australian teachers. These activities included a study undertaken during 1976 by the CDC to survey teachers' needs for information on curriculum products, which led to a trial project to implement a Curriculum Information Service between 1976 and 1979. Late in 1981, the Australian Education Council (AEC) established a Curriculum Materials Committee which recommended in 1982 that a national curriculum information service be established. It was not until after the CDC had been reactivated in 1984, however, that the information system developed by the ASCIS was used to input and store information on curriculum resources for subsequent dissemination to teachers. Cropley (1985) reported that collaboration was initiated between the CDC and other educational authorities in 1985 to develop the Australian Curriculum Information Network (ACIN). A national clearinghouse was established, and coordinators were appointed in each state and territory to collect and screen syllabuses, curriculum materials, curriculum policy statements, and curriculum research reports produced by educational organisations. Cropley (1987) reported that the Australian Thesaurus of Education Descriptors, developed for use with the Australian Education Index, was used to index records for the ACIN subfile, although the use of this controlled vocabulary was later abandoned so that the ACIN subfile would conform to other files and subfiles within the ASCIS database. Access to, the ACIN subfile of 1000 records was provided in October 1987 by microfiche updated every six months. The ACIN subfile has been expanded since that time to hold 6000 records.

Furthermore, the CDC was also involved in developing three additional subfiles in the database. Krystyn (1987) reported that the CDC was funded in 1986 to undertake planning for the National Software Coordination Unit (NSCU), following a feasibility study conducted by the Western Australian Educational Computing Consortium (1986). Founded in February 1987, this body held a National Workshop on Software for Education, formed a network for sharing information on computer education projects, and developed the Computer Software Review (CSR) subfile within the ASCIS database containing evaluations of microcomputer courseware. Berman (1987) stated that the indexes in the subfile were designed to provide information on publication, technical details, distribution, content description, and specifications of audiences and age groups for courseware. Online access to the CSR subfile became available in April 1988, and the service also provided microfiche updated every six months. At present, the CSR subfile contains 1,000 records.

Formed to promote a diverse range of activities to commemorate the bicentennial year in 1988 of the foundation of European settlement in 
Australia, the Australian Bicentennial Authority sponsored the CDC to develop the Bicentennial Australian Studies Schools Project as part of its national education program. The purpose of the project was to identify educational resources that support the teaching of Australian heritage studies. The resources identified during the course of the project included the Lu Rees Archives, a collection of children's literature housed in the University of Canberra. Information on these resources was indexed to form the Australian Studies subfile within the ASCIS database.

The National Aboriginal Education Committee and the CDC, in conjunction with state and territorial Aboriginal education consultative groups, initiated the Aboriginal and Torres Strait Islander Pedagogy Project, which developed the Aboriginal and Torres Strait Islander Resources (ATSIR) subfile. The aim of the project was to investigate, identify and promote teaching and learning approaches, as well as curriculum materials, to support the teaching of students of Aboriginal and Torres Strait Islander ethnicity. The ATSIR subfile, first made available by the Curriculum Corporation in 1991, provides information on resources concerned with both contemporary and traditional aspects of Aboriginal studies.

\section{The Curriculum Corporation}

The agenda for reform of the Australian educational system, a major priority of the Labor government during the latter part of the 1980s, led the Directors General of state education departments to examine how national and state educational authorities could collaborate to best effect through the AEC. In May 1988, the Minister for Employment, Education and Training invited the state educational authorities to cooperate towards developing a curriculum framework for Australian schools to include common objectives which also would accommodate specific content to meet particular regional needs (Dawkins, 1988). In agreeing to this proposal, the Australian Education Council (1989) recommended that the functions of the CDC and the ASCIS should be amalgamated within a new national agency to be named the Curriculum Corporation. Following its incorporation into the Commonwealth Department of Employment, Education and Training in 1987, the CDC officially ceased to function in 1989. The Curriculum Corporation did not actively commence operations, however, until the appointment of its Executive Director in May 1990.

The Curriculum Corporation, a company limited by guarantee, is governed by a Board of Directors consisting of representatives from each state and territory department of education (except New South Wales), the Commonwealth Department of Employment, Education and Training, the National Council of Independent Schools Associations, the National Catholic Education Commission, and the National Board of Employment, 
Education and Training. In addition, the New Zealand Department of Education became a member during 1991. When planning the functions of the Curriculum Corporation, the AEC decided that it should not be a policy-making body or be responsible for decision-making on curriculum issues. By subsuming the functions of the CDC and the ASCIS, it is intended that the Curriculum Corporation should continue to engage in collaborative activities with other educational organisations for the purpose of curriculum development. In an analysis of the structure and mode of operation proposed for the Curriculum Corporation by the AEC, Kemmis (1990) identified potential constraints arising from inadequate funding and the adoption of a centre-periphery view of curriculum research, development and evaluation modelled upon the past operations of the CDC, in which curriculum materials, pedagogies and modes of assessment are developed in consultation with senior administrators of state education systems. Kemmis argued that the Curriculum Corporation must combine this form of curriculum development with pedagogical and professional development at the school level, thereby providing teachers with the capacities and commitments to implement curriculum materials that support new curriculum proposals.

The mission of the Curriculum Corporation is to facilitate activities in curriculum development, to publish curriculum materials, and to provide curriculum information within the parameters of cooperation with collaborating organisations and client groups. This mission is accomplished through three main programs: Curriculum; Publishing; and Information. The goals of the' curriculum program are to undertake analysis and research related to national initiatives, undertake commissioned projects, to provide advisory services to member and other curriculum-related organisations, and provide advice to the AEC on national curriculum issues. The goals of the publishing program are to publish products of national collaborations on curriculum issues, publish selected materials for the AEC, publish products developed by member organisations and other curriculum-related organisations, and market publications and products through use of a catalogue and customer services. The information program, of particular relevance to this study, has the goals of increasing the use of library and curriculum information services and products, increasing awareness of accessible curriculum information for effective decision-making about learning and teaching, maintaining the accuracy and currency of information, managing selected curriculum information on the database relevant to national collaboration in curriculum development, improving access to information and its delivery to member systems and their Schools, providing cost effective collection, storage and dissemination of information on the database and 
its products and services, and assisting in the development of new products and services that are compatible with the needs of member systems.

In July 1986, the AEC adopted the strategy of identifying and drawing up lists of activities and materials, either existing or being undertaken by educational authorities in eight curriculum areas: mathematics; science; technology; English and literacy; study of society; health, physical education and personal development; the arts; and languages other than English. Each of the state and territorial departments of education was given responsibility for a particular curriculum area. This work, referred to as 'mapping the curriculum', was begun in 1988, and its scope has been surveyed and reported by the Curriculum Corporation (1991) according to the types of documents collected, whether policy statements, syllabuses, curriculum guides, professional materials, or curriculum materials. Hannan and Wilson (1992) reported that this work is being followed by two activities: the preparation and publication of national statements in each curriculum area outlining the main knowledge and skills of curriculum developers as references for developing curriculum guides; and the preparation, trial and publication of national profiles identifying strands for each curriculum area as a basis for reporting student achievement. The AEC recently established the AEC Curriculum and Assessment Committee (CURASS), comprising representatives of each state and territory department of education, the Commonwealth Department and Employment, Education and Training, the National Council of Independent Schools Association, the National Catholic Education Commission, the New Zealand Department of Education, the Australian Council for Educational Research, the New Zealand Council for Educational Research, the Curriculum Corporation, to manage the development of national statements and profiles. A schedule has been defined for completing the publication of briefs, statements and profiles in each curriculum area of the national framework by mid-1993.

\section{The extension of curriculum information}

This activity led to an extension of curriculum information on the database. In 1989, the AEC supported a proposal by the Victoria Ministry of Education to survey and evaluate curriculum materials available in Australia for environmental education. The Ballarat Community Education Centre in Victoria was contracted to conduct this project, which was undertaken between December 1989 and May 1990 and subsequently reported by the Victoria Ministry of Education (1990). The report of the survey indicated that the 765 curriculum materials available in Australia for environmental education are characterised by six main attributes: the predominant use of the print medium and neglect of non-print media; the failure to provide adequate materials for the early childhood and lower 
primary levels; a focus within the subject matter upon natural environment and resource management to the disadvantage of the social, cultural and economic environment; the failure to provide a crosscurricular emphasis; the lack of appropriate information analyses for users of the available materials; and the need for recognition to be given to the treatment of controversial issues in the materials. The report recommended that information analyses of the materials be provided in both print and online, that a national clearinghouse on environmental education be established by the Curriculum Corporation, and that guidelines be designed by the Curriculum Corporation for publishers to develop appropriate materials for environmental education. Records of information on curriculum materials, identified during this survey, were added to the database in 1991 to form the Environmental Education subfile.

In 1990, the AEC supported a proposal by the Aboriginal Education Advisory Group to survey and evaluate curriculum materials available in Australia for Aboriginal and Torres Strait Islander studies. As coordinator of the project, the South Australia Department of Education contracted the Education Curriculum Unit at Enfield, South Australia, to conduct this project, which was undertaken between July 1990 and October 1990, and subsequently reported by the South Australia Department of Education The report indicated that the survey identified 700 materials, including those already catalogued within the ATSIR subfile. These materials are characterised by four main attributes: curriculum materials constituted only a modestt proportion of the available products; most materials can be used in several grade levels, although few are specifically targeted to the lower and middle primary levels; the materials are available in various media, although multi-media packages were identified; and the subject matter focused upon contemporary and historical Aboriginal cultures. The report recommended that the findings of the survey be made available to the educational community and publishers in order to promote the development of curriculum for Aboriginal studies, that information analyses of the materials be provided in both print and online, and that guidelines be developed for curriculum materials for Aboriginal studies. The survey supported an extension of the work already undertaken by the Aboriginal and Torres Strait Islander Pedagogy Project.

Following the presentation by the Asian Studies Council (1988) of a strategy for the study of Asia in Australia, educational authorities implemented a range of programs for language and cultural studies in Australian schools. In response to an initiative by the Asian Studies Council, the Curriculum Corporation invited state departments of 
education in March 1990 to submit proposals to establish a Studies of Asia Information Service. Following a successful submission, the Tasmania Department of Education and the Arts collected information on curriculum materials available for Asian Studies from teachers of Asian languages, Asian Studies Council project groups, professional associations, and Asian studies and Asian language centres in Australian universities. Staff of the Curriculum Resources Section indexed and abstracted information on those curriculum and professional materials identified during the survey, to form the Asian Studies subfile, which consists of two components: one containing records supporting teaching about Asia; and the other relating to the teaching of Asian languages.

\section{The redesign of the database}

In 1991, the Board of Directors of the Curriculum Corporation agreed to redesign some components of the database inherited from the ASCIS, so that a new Curriculum Information Network (CIN) would support the common curriculum framework. The existing database consists of two files: the Schools Catalogue Information Service (SCIS) file containing 400,000 records; and six sub-files of curriculum-related records, the Curriculum Information Network containing 6,000 records, the Computer Software Review containing 1,000 records, the Australian Studies containing 1,850 records, the Aboriginal and Torres Strait Islanders Resources containing 1,200 records, the Environmental Education containing 700 records, and the Asian Studies and Asian Languages containing 1,300 records. It is proposed that the six sub-files of curriculum related records, contained in the existing database, will be reordered into new sub-files to form a CIN file, according to whether the subject matter relates to an across-the-curriculum emphasis or to any one of eight curriculum areas. It is proposed that records published in 1988 or later, be reorganised into the new CIN sub-files by the addition of curriculum area identifiers something after 1992, and that new abstracting standards be specified for new records and that selected, existing records be reformatted according to the new standards.

As part of the redesign of the ASCIS database, the Curriculum Corporation initiated an offline search service, entitled the Teachers Curriculum Search and Information Service (TECSIS), for a trial period during 1991 and 1992, which provided customised reports from the ASCIS database for $\$ 8.00$ plus 20 cents per record, and from the Australian Associated Press database for an additional $\$ 8.00$ plus 20 cents per record. At present, the database is also accessible online which includes an electronic mail facility and bulletin board, by micrographic application, and catalogue card and related services are provided. Clients can access the online service through the choice of two options; either by payment of an annual subscription of $\$ 125.00$ plus a fee of $\$ 30.00$ per hour connect 
time, or by payment of a fee of $\$ 40.00$ per hour connect time. The Curriculum Corporation also markets records from its database in a-series of microfiche collections: the full SCIS records and subject authority for 999.00; the full SCIS records for \$85.00; the abbreviated SCIS records and subject authority for $\$ 99.00$; the SCIS subject authority for $\$ 20.00$; the six subfiles of curriculum-related records of the Curriculum Information Network, the Computer Software Review, the Australian Studies, the Aboriginal and Torres Strait Islanders Resources, the Environmental Education, and the Asian studies and Asian Languages for \$30.00 each. Brewer et al (1992) reported that the board of the Curriculum Corporation recently decided to suspend the dissemination of these six subfiles from July 1992, because continued lack of subscriptions from users made this service uneconomic. The information in these sub-files will remain passive until a decision is made about the future of this service. The Curriculum Corporation also markets ASCIS80, SCIS records as machine readable records on disc for 60 cents per record, catalogue cards for 60 cents per set or with cross-references linking related subjects for 25 cents per card, and ASCISRECON, a computer program for IBM compatible microcomputers, which converts a school library card catalogue to an automated access system, for $\$ 110.00$ plus 15 cents per record. A selection of 8,135 curriculum-related records within the database is also available, together with twelve other databases, on one CD-ROM marketed by the Curriculum Corporation and INFORMIT, Royal Melbourne Institute of Technology, as AUSTROM (Australian Social Science, Law and Education Databases on CD-ROM) for an annual subscription of $\$ 1,495.00$ and at a discounted annual subscription of $\$ 745.00$ to schools. This product includes updates at four-month intervals, and runs on an IBM compatible microcomputer with a CD-ROM drive.

\section{Conclusion}

The evidence provided by this historical and developmental study of the design of the national information service for Australian teachers confirms the contention that its provision is driven by political and economic considerations rather than those based upon the requirements of research and development, the trialing and assimilation of services, the training of personnel and the needs of teachers. This view is supported by the evident incompleteness and lack of internal consistency within the organisation of the information System, its use of practices, techniques and methods for inputting information that do not relate to the principles of curriculum design, and its reliance upon older technologies, such as microforms, for outputting information, instead of an adequate application of recent optical publishing technology. On the other hand, it is apparent that many 
Australian teachers have yet to use electronic information services and to value the provision of curriculum information.

This situation contrasts with information services available in other developed countries, which appear to be more coherently organised. Since 1967, the Educational Products Information Exchange (EPIE) Institute has used in the United States a variety of practices, techniques and methods, including processes to provide learner verification and revision of instructional materials, instructional design analyses of commercial and non-commercial materials, and more recently the principles of curriculum alignment applied within a database, the Integrated Instructional Information Resource (IIIR). Curriculum planners in Canada have adapted practices, techniques and methods derived from the EPIE Institute to establish the Canadian Exchange for Instructional Materials Analysis (CEIMA) in 1983, a consortium for exchanging curriculum information between the provincial departments of education in British Columbia, Alberta and Manitoba. In 1986, the Department of Trade and Industry in the United Kingdom funded a two-year project to design the National Educational Resources Information Service (NERIS) for the purpose of providing an electronic information service for schools. In 1988, the newly founded NERIS Trust was funded by the British government to develop products and services that would meet the requirements of the National Curriculum, then recently implemented in schools throughout the United Kingdom.

Whereas the redesign of the information system, prompted by the need for the Curriculum Corporation to provide relevant information relating to the national curriculum framework, is likely to improve the quality of products and services, it can be contended that substantial improvement will only occur as a result of the adoption of practices, techniques and methods applied in foreign settings. It is anticipated that these practices, techniques and methods could be applied successfully, thereby redressing shortcomings for which solutions have not been provided in the past by Australian curriculum planners.

\section{References}

Asian Studies Council (1988). A National Strategy for the Study of Asia in Australia. Canberra, ACT: Australian Government Publishing Service.

Australian Education Council (1989). The Hobart Declaration on Schooling. Melbourne, Vic: Australian Education Council.

Australian Schools Catalogue Information Service (1985). ASCIS Subject Headings List . Port Melbourne, Vic: D. W. Thorpe.

Australian Schools Catalogue Information Service Steering Committee (1980).Australian Schools Catalogue Information Service: Final Report to the Schools Commissionfrom the ASCIS Steering Committee. Canberra, ACT: Commonwealth Schools Commission. 
Bahnisch, B. (1983). The Australian Schools Catalogue Information Service (ASCIS).Joumal of the School Library Association of Queensland, 15(3), 16-19.

Berman, P. (1987). NSCU: The National Software Coordination Unit. Curriculum Development in Australian Schools, 5, 18.

Brewer,W., Keating, J. \& Levitt, C. (1992). News from the Curriculum Corporation. Curriculum Perspectives, 12(2), 22-24.

Broadbent, M. (1983). Networking, school libraries and curriculum information: curent issues and concerns.The Australian Library Journal, 32(2),3-10.

Broadbent, M. and Kemp, B. (1983). Meeting curriculum information needs. Curriculum Perspectives, 3(2), 1-7.

Cropley, M. (1985). CDC is bringing together a national network of information on curriculum.Curriculum Development in Australian Schools, 1, 34.

Cropley, M. (1987). First came the computer, then the modem, now the Australian Curriculum Information Network. Curriculum Development in Australian Schools, 3, 32.

Curriculum Corporation (1991). National Collaboration in Curriculum: a National Survey of Current Curriculum Strengths, Interests and Needs. Melboume,Vic: Curriculum Corporation.

Dawkins, J. S. (1988). Strengthening Australia's Schools: a Consideration of the Focus and Content of Schooling. Canberra, ACT: Australia Parliament.

Dwyer, J. G. (1978). SAERIS and ASCIS: a non-technical overview. The Australian Library Joumal, 27(17), 283-285.

Dwyer, J. G. (1988). ASCIS (Australian Schools Catalogue Information Service). In Bryan, H. (ed.), Australia's Library, Information and Archives Services: An Encyclopaedia of Practice and Practitioners. Sydney, NSW: Library Association of Australia, vol. 1, 28-29.

Goodman, D. (1980). ASCIS Pilot Project (1978-1980): an assessment. Australian School Librarian, 17(3), 81-84.

Hannan, B. \& Wilson, B. (1992). The development of a national curriculum framework. Curriculum Perspectives, 12(2), 2-3.

Hughes, P. and Kennedy, K. K. (1987). Evaluating the impact of the Curriculum Centre in Australia. Studies in Educational Evaluation, 13(3), 297-305.

Kemmis, S. (1990). The Curriculum Corporation: Observations and Implications. (Occasional Paper Number 1). Spring Hill, Qld: Australian Curriculum Studies Association.

Krystyn, J. (1987). The National Software Coordination Unit takes another step towards reality. Curriculum Development in Australian Schools, 3, 35.

Lane, N. D. and Chisholm, M. E. (1984). Technology in school libraries in Australia. Drexel Library Quarterly, 20(1), 85-105.

Moran, B. (1980). The Establishment of a National Curriculum Development Centre. Canberra, ACT: Curriculum Development Centre. 
South Australia Department of Education (1991). Audit and Evaluation of K12 Aboriginal and Torres Strait Islander Studies Materials. Adelaide, SA: South Australia Department of Education.

Victoria Ministry of Education (1990). Audit and Evaluation of Environmental Education Materials. Melbourne, Vic: Victoria Ministry of Education.

Watt, M. G. (1989). The exchange of information on instructional materials: an evaluation for planned change in Australian education. Australian Journal of Educational Technology, 5(2), 77-88. http: / / www.ascilite.org.au/ajet/ ajet5/watt.html

Watt, M. G. (1991). Selecting instructional materials: a survey of decision making processes. Orana, 27(2), 108-116.

Western Australian Educational Computing Consortium (1986). National Software Clearinghouse Feasibility Study: Report to Commonwealth Curriculum Development Centre. Perth: Western Australian Educational Computing Consortium.

\section{Acknowledgment}

The author wishes to acknowledge the contribution of Mr Warren Brewer, Curriculum and Information Manager of the Curriculum Corporation in reviewing this article.

Author: Michael G. Watt has taught in several schools in Tasmania, and worked as an education officer in the Curriculum Services Section of the Tasmanian Department of Education and the Arts. In 1991, he commenced full-time study towards a PhD degree. He can be contacted at 316 Churchill Avenue, Sandy Bay, Tasmania 7005.

Please cite as: Watt, M. G. (1992). The exchange of curriculum information in Australian education: A review of purposes, practices, and problems. Australian Journal of Educational Technology, 8(2), 105-118. http: / www.ascilite.org.au/ajet/ajet8/watt.html 